\title{
Key Success Factors in Implementing Business Process Re-Engineering (BPR) in Hospitals: Integrative Review
}

\author{
Nurfadhilah $^{1}$, Andi Indahwaty Sidin ${ }^{1}$, Abdul Rahman Kadir ${ }^{2}$ \\ ${ }^{1}$ Hospital Management Department, Faculty of Public Health, Hasanuddin University, \\ Indonesia \\ ${ }^{2}$ Management Department, Faculty of Economics and Business, Hasanuddin University, \\ Indonesia
}

Received: June 15, 2021

Received in Revised: July 12, 2021

Accepted: August 2, 2021

\begin{abstract}
BPR is one of the most important ways for hospitals to make changes so that they can improve their efficiency and effectiveness. However, in practice, BPR in hospitals encountered many challenges and in the end did not achieve the expected results. Various studies have described the factors that lead to success or failure in the implementation of BPR projects so that the purpose of this study is to analyze the key factors that lead to success in implementing BPR in hospitals. This integrative review uses the Joanna Briggs Institute guidelines with primary research articles in English which are accessed through the PubMed, ScienceDirect, and Google Scholar databases for the last 10 years. The article search results obtained 311 articles and the remaining 10 articles were included in the study. The results of the study obtained nine key success factors in implementing BPR in hospitals, namely management commitment, employee empowerment, methods and tools, information technology, environment and culture, external organization, BPR projects, finance and strategy. These factors are only generally representative of various hospitals including public and private hospitals because there are many other factors that can affect the implementation of BPR depending on the type, characteristics, and heterogeneous hospital environment. It is hoped that this key factor will be a concern when the hospital wants to make changes through the BPR project and can assist the hospital in achieving results according to the organization's vision.
\end{abstract}

Keywords: Business Process Re-Engineering, Success Factors, BPR, Implementation, Hospital

\section{Introduction}

Hospitals are one of the service industries with very complex and dynamic business processes, starting from the procurement system, data collection and distribution of medicines, involvement of clinical and administrative officers to the process of providing services to patients, which of course has the potential for significant optimization and efficiency improvements (Arinahaq \& Achadi, 2019; Mmereki \& Moruisi, 2013; Pujawan, 2007). ReEngineering or re-engineering can assist the hospital in systematically overcoming work barriers that occur when the management strives to provide the highest satisfaction for internal and external customers of the hospital.

According to Hammer and Champy (1993), Business Process Re-engineering (BPR) is a fundamental rethinking and radical redesign of an organization's business processes that leads an organization to achieve dramatic improvements in its business performance both in terms of cost, time, service, and quality (Brennan et al., 2005; Elkhuizen et al., 2006; Grocott et al., 2017; Khodambashi, 2013; Patwardhan \& Patwardhan, 2008; Sungau, 2013). BPR can be seen

Copyright (0 2021, Journal of Asian Multicultural Research for Medical and Health Science Study, Under the license CC BY-SA 4.0 
as an operationally oriented process that is directly linked to products and customers, as well as; is actually a management-oriented process that is primarily based on organizational resources (Al-fawaeer et al., 2019). BPR is a way for organizations to improve customer value proposition which consists of three variables, namely (1) product leadership (excellent product or speed), (2) operational excellence (low cost, high quality and excellent service), and (3) customer intimacy. (customization, long term and deep relationship) (Putra \& Puspitorini, 2017).

A study in Egypt at six hospitals showed that there was a significant increase in the number of patient visits after the implementation of business process re-engineering, both recipients and service providers were satisfied after the implementation of BPR (Rateb et al., 2011). Several studies have shown that BPR is able to reduce service waiting times (Al Badi, 2018; BlouinDelisle et al., 2018; Grocott et al., 2017) and able to improve the effectiveness of hospital information systems (Khodambashi, 2013; Ruffin, 2016). Research results by Helfert (2009) in Ireland stated that although process management in health care is very important, there are currently very few international guidelines available to introduce process management in hospitals. according to Kohlbacher (2010) It should be noted that business processes in health care are more difficult to manage and reform because they are limited to the service itself and often involve interactions with other groups and companies. This is supported by opinion Jamali et al. (2011) that BPR implementation is a difficult task.

Evidently several reports show that the failure rate of BPR implementation reaches $70 \%$ (AlMashari et al., 2001; Boudreau \& Robey, 1996; O’Neill \& Sohal, 1999; Rao et al., 2012). So that a deeper study is needed on the redesign process in health care, especially on how to choose the best operations management practices that are suitable for implementation (Sousa \& Voss, 2008 in Feibert et al., 2019; Elkhuizen et al., 2006; Jamali et al., 2011). According to CacciaBava et al. (2013) further research is needed on the success factors of BPR and testing its application in hospitals. Research result Musa \& Othman (2016) shows that research related to BPR in health services using the review method is still very low at only about $7 \%$. The purpose of this study is to identify and conduct a mapping study of the key success factors of BPR so that hospitals can select and implement best practices in BPR implementation and be able to achieve success

\section{Methods}

This study uses a review method with an integrative review research design. Researchers can use integrative review to answer a question by including various research methods and designs. The research guide used is JBI (Joanna Briggs Institute). The search for articles was carried out in two stages, namely through the Science Direct, Pubmed, and Google Scholar Advance databases, and secondly, tracing the reference list of the identified articles. The articles identified were in English which were published in the last 10 years from January 2011 to December 2020 and focused on the implementation of BPR in hospitals. The flow of literature selection will be presented in a chart according to PRISMA standards. Presentation of data from studies that have been included in the final results, will be extracted and then made in narrative form and presented in a data table consisting of: author, year of publication, research title, objectives, research design, population and research sample, country, and research results

\section{Results and Discussion}

The search results of scientific articles in three databases obtained 934 articles (study selection flow in Figure 1). Then the articles were eliminated according to the year of publication from 2011-2020 and 311 scientific articles were obtained. The articles were then screened based on titles and abstracts that did not meet the criteria as well as duplicate articles in each database.

Copyright (O) 2021, Journal of Asian Multicultural Research for Medical and Health Science Study, Under the license CC BY-SA 4.0 
From the identification of publications, 37 duplicate articles were obtained and from 274 articles, 214 articles did not meet the criteria based on the title and abstract. The result is that there are 60 articles that were downloaded in full text to be analyzed according to the inclusion criteria. Finally, 9 articles were included in this integrative review study plus 1 article from the secondary search results through the reference list.

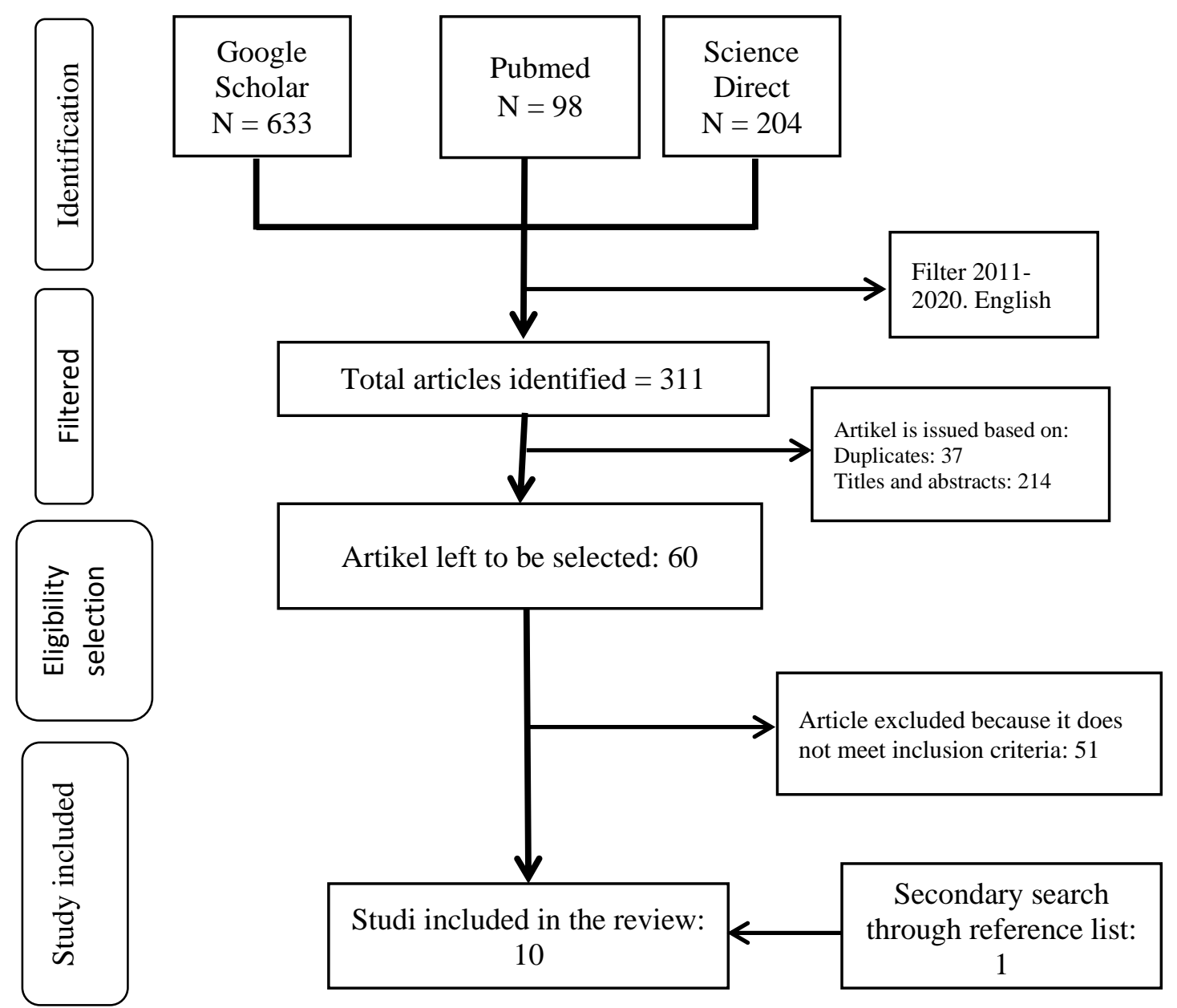

Figure 1. Study Search Algorithm

Articles are presented in a data table consisting of: author, year of publication, research title, research design and sample, data collection and analysis, quality, journal, research results, and grouping of BPR factors. In assessing the quality of the sources of research evidence included in this review study, it is carried out using a checklist of standard quality assessment criteria for evaluating primary research papers from a variety of fields.

Tabel 1. Article Description in the Study

\begin{tabular}{|c|c|c|c|c|c|c|c|}
\hline No & $\begin{array}{c}\text { Researcher } \\
\text { (Year) }\end{array}$ & Tittle & $\begin{array}{c}\text { Design and } \\
\text { Samples }\end{array}$ & $\begin{array}{c}\text { Data } \\
\text { collection }\end{array}$ & Methods of analysis & quality & Journal \\
\hline 1 & $\begin{array}{l}\text { Putro, F. X. A. } \\
\text { N. S., \& } \\
\text { Dachyar, M. } \\
(2020) \\
\text { Indonesia }\end{array}$ & $\begin{array}{l}\text { Hospital Surgical } \\
\text { Services Design } \\
\text { Improvement Using } \\
\text { Business Process } \\
\text { Re-Engineering and } \\
\text { Relational Database } \\
\text { Approaches }\end{array}$ & $\begin{array}{l}\text { Qualitative } \\
\text { (designing } \\
\text { scenario) }\end{array}$ & $\begin{array}{l}\text { Literature } \\
\text { study and } \\
\text { observation } \\
\text { and interviews. }\end{array}$ & $\begin{array}{l}\text { The surgical service } \\
\text { process is modeled } \\
\text { and simulated with } \\
\text { the iGrafx software. } \\
\text { Then design some } \\
\text { scenarios. }\end{array}$ & $17 / 22$ & $\begin{array}{l}\text { International } \\
\text { Journal of } \\
\text { Advanced } \\
\text { Science and } \\
\text { Technology }\end{array}$ \\
\hline
\end{tabular}




\begin{tabular}{|c|c|c|c|c|c|c|c|}
\hline No & $\begin{array}{l}\text { Researcher } \\
\text { (Year) }\end{array}$ & Tittle & $\begin{array}{l}\text { Design and } \\
\text { Samples }\end{array}$ & $\begin{array}{c}\text { Data } \\
\text { collection }\end{array}$ & Methods of analysis & quality & Journal \\
\hline 2 & $\begin{array}{l}\text { Olajide, O. T., } \\
\text { Lawal, O. R., } \\
\text { \& Alaka, S. N. } \\
\text { (2019) } \\
\text { Nigeria }\end{array}$ & $\begin{array}{l}\text { Effects of Business } \\
\text { Process Re- } \\
\text { Engineering on } \\
\text { Performance of } \\
\text { Selected Hospitals } \\
\text { in Lagos State }\end{array}$ & $\begin{array}{l}\text { Quantitative } \\
\text { Survey, } 46 \\
\text { private } \\
\text { hospital staff } \\
\text { and } 157 \\
\text { public } \\
\text { hospital staff }\end{array}$ & Questionnaire & $\begin{array}{l}\text { Correlation analysis } \\
\text { with the help of } \\
\text { SPSS. }\end{array}$ & $21 / 22$ & $\begin{array}{l}\text { Annals of the } \\
\text { University of } \\
\text { Craiova, } \\
\text { Economic } \\
\text { Sciences Series }\end{array}$ \\
\hline 3 & $\begin{array}{l}\text { Manyazewal, } \\
\text { T., \& } \\
\text { Matlakala, M. } \\
\text { C. (2018) } \\
\text { Ethiopia }\end{array}$ & $\begin{array}{l}\text { Implementing } \\
\text { health care reform: } \\
\text { implications for } \\
\text { performance of } \\
\text { public hospitals in } \\
\text { central Ethiopia }\end{array}$ & $\begin{array}{l}\text { Cross- } \\
\text { sectional } \\
\text { study, } 476 \\
\text { health } \\
\text { workers }\end{array}$ & Questionnaire & $\begin{array}{l}\text { Statistical method } \\
\text { (Non-parametric } \\
\text { analysis) }\end{array}$ & $20 / 22$ & $\begin{array}{l}\text { Journal of } \\
\text { Global Health }\end{array}$ \\
\hline 4 & $\begin{array}{l}\text { Musa, M. A. } \\
\text { (2017) } \\
\text { Nigeria }\end{array}$ & $\begin{array}{l}\text { Critical Success } \\
\text { Factor in Business } \\
\text { Process } \\
\text { Reengineering In } \\
\text { Healthcare: An } \\
\text { Exploratory } \\
\text { Investigations }\end{array}$ & $\begin{array}{l}\text { Quantitative, } \\
520 \\
\text { respondents }\end{array}$ & Questionnaire & $\begin{array}{l}\text { Statistical method } \\
\text { (Exploratory factor } \\
\text { analysis) }\end{array}$ & $20 / 22$ & $\begin{array}{l}\text { Journal of } \\
\text { Multidisciplina } \\
\text { ry Engineering } \\
\text { Science and } \\
\text { Technology } \\
\text { (JMEST) }\end{array}$ \\
\hline 5 & $\begin{array}{l}\text { Leggat, S. G., } \\
\text { Gough, R., } \\
\text { Bartram, T., } \\
\text { Stanton, P., } \\
\text { Bamber, G. J., } \\
\text { Ballardie, R., } \\
\text { \& Sohal, A. } \\
\text { (2016) } \\
\text { Australia }\end{array}$ & $\begin{array}{l}\text { Process Redesign } \\
\text { for Time-Based } \\
\text { Emergency } \\
\text { Admission Targets: } \\
\text { Staff Perceptions of } \\
\text { The Impact on } \\
\text { Quality of Care }\end{array}$ & $\begin{array}{l}\text { Retrospective } \\
\text { Qualitative } \\
\text { case study, } \\
26 \\
\text { respondents }\end{array}$ & $\begin{array}{l}\text { Semi- } \\
\text { structured } \\
\text { interview }\end{array}$ & $\begin{array}{l}\text { Conventional } \\
\text { Thematic Content } \\
\text { Analysis }\end{array}$ & $19 / 22$ & $\begin{array}{l}\text { Journal of } \\
\text { Health } \\
\text { Organization } \\
\text { and } \\
\text { Management }\end{array}$ \\
\hline 6 & $\begin{array}{l}\text { Manyazewal, } \\
\text { T., } \\
\text { Oosthuizen, } \\
\text { M. J., \& } \\
\text { Matlakala, M. } \\
\text { C. (2016) } \\
\text { Ethiopia }\end{array}$ & $\begin{array}{l}\text { Proposing } \\
\text { Evidence-Based } \\
\text { Strategies to } \\
\text { Strengthen } \\
\text { Implementation of } \\
\text { Healthcare Reform } \\
\text { in Resource- } \\
\text { Limited Settings: A } \\
\text { Summative } \\
\text { Analysis }\end{array}$ & $\begin{array}{l}\text { Descriptive } \\
\text { and } \\
\text { exploratory } \\
\text { design, } 406 \\
\text { health } \\
\text { professionals } \\
\text { and } 10 \text { senior } \\
\text { health policy } \\
\text { experts. }\end{array}$ & Questionnaire & Summative Analysis & $19 / 22$ & BMJ Open \\
\hline 7 & $\begin{array}{l}\text { Leggat, S. G., } \\
\text { Bartram, T., } \\
\text { Stanton, P., } \\
\text { Bamber, G. J., } \\
\text { \& Sohal, A. S. } \\
\text { (2015) } \\
\text { Australia }\end{array}$ & $\begin{array}{l}\text { Have Process } \\
\text { Redesign Methods, } \\
\text { Such As Lean, } \\
\text { Been Successful in } \\
\text { Changing Care } \\
\text { Delivery in } \\
\text { Hospitals? A } \\
\text { Systematic Review }\end{array}$ & $\begin{array}{l}\text { Systematic } \\
\text { review, } 41 \\
\text { studies }\end{array}$ & $\begin{array}{l}\text { Literature } \\
\text { searches from } \\
\text { the Cochrane } \\
\text { Register, } \\
\text { Medline, } \\
\text { PubMed, and } \\
\text { CINAHL and } \\
\text { G. Scholar }\end{array}$ & No statistical analysis & $17 / 22$ & $\begin{array}{l}\text { Public Money } \\
\& \text { Management }\end{array}$ \\
\hline 8 & $\begin{array}{l}\text { Caccia-Bava, } \\
\text { M. C., } \\
\text { Guimaraes, V. } \\
\text { C., \& } \\
\text { Guimaraes, T. } \\
\text { (2013) } \\
\text { USA }\end{array}$ & $\begin{array}{l}\text { Important Factors } \\
\text { for Success in } \\
\text { Hospital BPR } \\
\text { Project Phases }\end{array}$ & $\begin{array}{l}\text { Cross- } \\
\text { departmental } \\
\text { process and } \\
\text { change study, } \\
192 \\
\text { Administrator } \\
\text { RS }\end{array}$ & Questionnaire & $\begin{array}{l}\text { Statistical Method } \\
\text { (Factor analysis } \\
\text { using Varimax } \\
\text { rotation) }\end{array}$ & $20 / 22$ & $\begin{array}{l}\text { International } \\
\text { journal of } \\
\text { health care } \\
\text { quality } \\
\text { assurance }\end{array}$ \\
\hline 9 & $\begin{array}{l}\text { Khodambashi, } \\
\text { S. (2013) } \\
\text { Norwegia }\end{array}$ & $\begin{array}{l}\text { Business Process } \\
\text { Re-Engineering } \\
\text { Application in } \\
\text { Healthcare in A } \\
\text { Relation to Health } \\
\text { Information } \\
\text { Systems }\end{array}$ & $\begin{array}{l}\text { Literature } \\
\text { review, } 5 \\
\text { studies }\end{array}$ & $\begin{array}{l}\text { Open literature } \\
\text { search }\end{array}$ & $\begin{array}{l}\text { No statistical analysis } \\
\text { (Manual analysis) }\end{array}$ & $17 / 22$ & $\begin{array}{l}\text { Procedia } \\
\text { Technology }\end{array}$ \\
\hline
\end{tabular}




\begin{tabular}{|c|l|l|l|l|l|l|l|}
\hline No & \multicolumn{1}{|c|}{$\begin{array}{c}\text { Researcher } \\
\text { (Year) }\end{array}$} & \multicolumn{1}{|c|}{ Tittle } & $\begin{array}{c}\text { Design and } \\
\text { Samples }\end{array}$ & \multicolumn{1}{c|}{$\begin{array}{c}\text { Data } \\
\text { collection }\end{array}$} & Methods of analysis & quality & \multicolumn{1}{|c|}{ Journal } \\
\hline 10 & Mmereki, R. & Challenges in & Case studies, & Interview & Alternative analytic & $17 / 22$ & International \\
& N., \& Moruisi, & Implementation of \\
& K. G. (2013) & some & Business Process \\
employees & & & $\begin{array}{l}\text { experience and } \\
\text { literature) }\end{array}$ & & $\begin{array}{l}\text { Customer } \\
\text { Relations }\end{array}$ \\
& Botswana & $\begin{array}{l}\text { Re-Engineering in } \\
\text { Botswana Public } \\
\text { Hospitals. }\end{array}$ & & & & & \\
\hline
\end{tabular}

Table 2. Research Results

\begin{tabular}{|c|c|c|c|}
\hline No & $\begin{array}{l}\text { Researcher } \\
\text { (Year) }\end{array}$ & Research Results & BPR Success Factor \\
\hline 1 & $\begin{array}{l}\text { Putro, F. X. A. } \\
\text { N. S., \& } \\
\text { Dachyar, M. } \\
(2020)\end{array}$ & $\begin{array}{l}\text { This study provides six scenario options for } \\
\text { hospital surgery services. Each scenario results } \\
\text { in a different service time. The scenario consists } \\
\text { of three classifications of solutions: parallel, } \\
\text { information systems and RFID technology. The } \\
\text { sixth scenario uses parallel, information systems } \\
\text { and RFID technology solutions which is the } \\
\text { most complete scenario. }\end{array}$ & $\begin{array}{ll}\text { 1. } & \text { Financial } \\
\text { 2. } & \text { Human Resources }\end{array}$ \\
\hline 2 & $\begin{array}{l}\text { Olajide, O. T., } \\
\text { Lawal, O. R., } \\
\text { \& Alaka, S. N. } \\
(2019) .\end{array}$ & $\begin{array}{l}\text { There is a positive correlation between business } \\
\text { process renovation and operational } \\
\text { effectiveness, also the second hypothesis shows } \\
\text { that there is a positive relationship between } \\
\text { process automation and competitive advantage } \\
\text { and finally, management support has a } \\
\text { significant positive effect on service quality in } \\
\text { hospitals in Lagos State, Nigeria. }\end{array}$ & 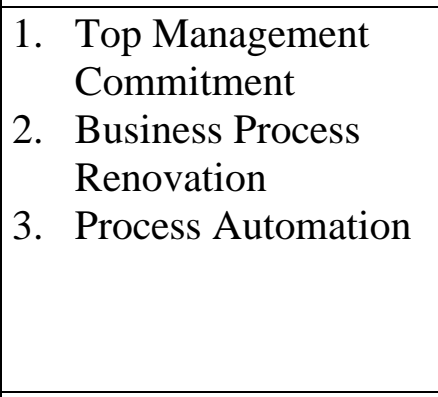 \\
\hline 3 & $\begin{array}{l}\text { Manyazewal, } \\
\text { T., \& } \\
\text { Matlakala, M. } \\
\text { C. (2018) }\end{array}$ & $\begin{array}{l}\text { The main obstacles to reform are the work } \\
\text { environment (adjusted odds ratio }(\mathrm{aOR})=2.27 \text {, } \\
95 \% \text { confidence interval }(\mathrm{CI}): 1.15-4.47) \text {, } \\
\text { financial resources }(\mathrm{aOR}=3.54,95 \% \mathrm{CI}=1,97 \text { - } \\
6.33) \text {, management }(\mathrm{aOR}=2.27,95 \% \mathrm{CI}=1.15 \text { - } \\
4.47) \text {, and information technology systems } \\
(\mathrm{aOR}=3.15,95 \% \mathrm{CI}=1.57-6.32) \text {. }\end{array}$ & $\begin{array}{ll}\text { 1. } & \text { Work environment } \\
\text { 2. } & \text { Financial Resources } \\
\text { 3. } & \text { Management } \\
\text { 4. } & \text { Information } \\
& \text { Technology System }\end{array}$ \\
\hline 4 & $\begin{array}{l}\text { Musa, M. A. } \\
(2017)\end{array}$ & $\begin{array}{l}\text { The results showed that the measurement of IT } \\
\text { effectiveness at BPR (UIT4) which has the } \\
\text { highest validity coefficient of } 0.89 \text { is the most } \\
\text { critical indicator for BPR implementation. }\end{array}$ & 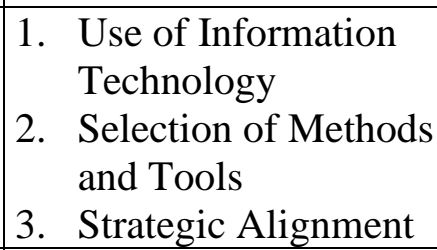 \\
\hline 5 & $\begin{array}{l}\text { Leggat, S. G., } \\
\text { Gough, R., } \\
\text { Bartram, T., } \\
\text { Stanton, P., } \\
\text { Bamber, G. J., } \\
\text { Ballardie, R., } \\
\text { \& Sohal, A. } \\
\text { (2016) }\end{array}$ & $\begin{array}{l}\text { There are four important findings. First, when } \\
\text { asked to comment on the impact of } \\
\text { implementing the LSS, staff were not asked to } \\
\text { talk about the quality of care. Second, there was } \\
\text { little agreement among the participants as to } \\
\text { whether the project had been successful. Third, } \\
\text { despite the recognition of the need for } \\
\text { coordinated efforts across hospitals to improve } \\
\text { ED access, the redesign process did not succeed } \\
\text { in reducing the gaps that existed between } \\
\text { physicians and between managers and } \\
\text { physicians. Fourth, staff expressed tension }\end{array}$ & $\begin{array}{ll}\text { 1. } & \text { Management Support } \\
\text { 2. } & \text { Staff Participation } \\
\text { 3. } & \text { BPR process } \\
& \text { indicators }\end{array}$ \\
\hline
\end{tabular}

Copyright @ 2021, Journal of Asian Multicultural Research for Medical and Health Science Study, Under the license CC BY-SA 4.0 


\begin{tabular}{|c|c|c|c|}
\hline No & $\begin{array}{c}\text { Researcher } \\
\text { (Year) }\end{array}$ & Research Results & BPR Success Factor \\
\hline & & $\begin{array}{l}\text { between the process of moving patients more } \\
\text { quickly and their duty to care for patients as } \\
\text { individuals. }\end{array}$ & \\
\hline 6 & $\begin{array}{l}\text { Manyazewal, } \\
\text { T., } \\
\text { Oosthuizen, } \\
\text { M. J., \& } \\
\text { Matlakala, M. } \\
\text { C. (2016) }\end{array}$ & $\begin{array}{l}\text { The health care reforms evaluated were able to } \\
\text { restructure hospital departments into case teams, } \\
\text { with the aim of adopting a 'one-stop shopping' } \\
\text { approach. The most important predictors } \\
\text { influencing the implementation of reforms are } \\
\text { financial resources, top management } \\
\text { commitment and support, collaborative work } \\
\text { environment and information technology (IT). }\end{array}$ & $\begin{array}{ll}\text { 1. } & \text { Financial Resources } \\
\text { 2. } & \text { Top Management } \\
& \text { Commitment and } \\
& \text { Support } \\
\text { 3. } & \text { Collaborative Work } \\
& \text { Environment } \\
\text { 4. } & \text { Information } \\
& \text { Technology }\end{array}$ \\
\hline 7 & $\begin{array}{l}\text { Leggat, S. G., } \\
\text { Bartram, T., } \\
\text { Stanton, P., } \\
\text { Bamber, G. J., } \\
\text { \& Sohal, A. S. } \\
(2015) .\end{array}$ & $\begin{array}{l}\text { Success factors for the change include } \\
\text { mechanisms to facilitate participation } \\
\text { throughout the process, clearly documented } \\
\text { protocols and expectations for health workers } \\
\text { supported by education, mechanisms to audit } \\
\text { and provide feedback on behavior and } \\
\text { performance. The success of the process } \\
\text { redesign methodology was found to be highly } \\
\text { dependent on these performance-based human } \\
\text { resource management (HR) practices. }\end{array}$ & 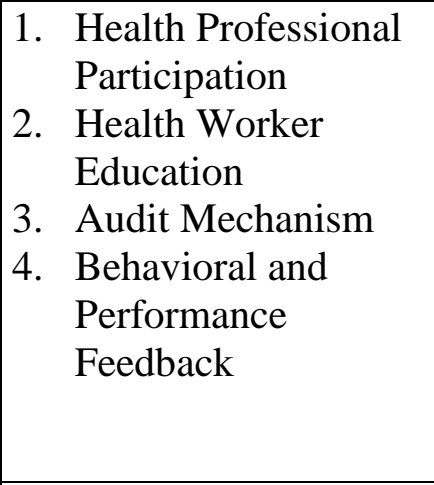 \\
\hline 8 & $\begin{array}{l}\text { Caccia-Bava, } \\
\text { M. C., } \\
\text { Guimaraes, V. } \\
\text { C., \& } \\
\text { Guimaraes, T. } \\
(2013)\end{array}$ & $\begin{array}{l}\text { The items identified in the literature as critical } \\
\text { to BPR success fall into five separate groups } \\
\text { that address: project team cohesiveness; the } \\
\text { process used by the project team to implement } \\
\text { BPR; the expertise available to the project team } \\
\text { regarding the process being } \\
\text { redesigned/reengineered; IT support extended to } \\
\text { the project; and project leadership and } \\
\text { motivation. }\end{array}$ & 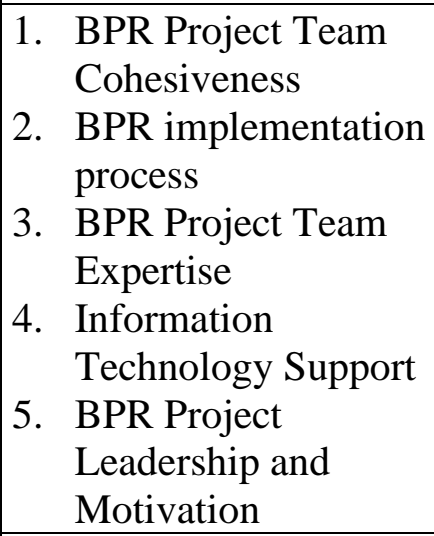 \\
\hline 9 & $\begin{array}{l}\text { Khodambashi, } \\
\text { S. (2013) }\end{array}$ & $\begin{array}{l}\text { User involvement is an important aspect in the } \\
\text { implementation of BPR. The participation of } \\
\text { operational staff is important because they know } \\
\text { the process best and it would be better if they } \\
\text { were given ownership of the BPR. In BPR, it is } \\
\text { important for software specialists and analysts } \\
\text { or development teams to communicate } \\
\text { effectively and work closely together as they } \\
\text { have their own perspective, vocabulary and } \\
\text { methods on the process. User training, } \\
\text { management commitment, clear concrete } \\
\text { objectives and sponsorship for BPR projects are } \\
\text { important determinants of successful BPR } \\
\text { implementation. The implementation of BPR } \\
\text { before the implementation of the Health } \\
\text { Information System (SIK) or even after }\end{array}$ & 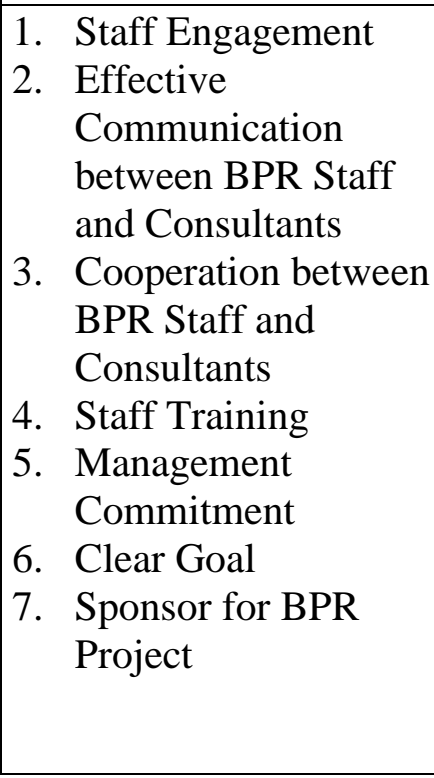 \\
\hline
\end{tabular}

Copyright @ 2021, Journal of Asian Multicultural Research for Medical and Health Science Study, Under the license CC BY-SA 4.0 


\begin{tabular}{|c|c|c|c|}
\hline No & $\begin{array}{l}\text { Researcher } \\
\text { (Year) }\end{array}$ & Research Results & BPR Success Factor \\
\hline & & $\begin{array}{l}\text { implementation can help increase the } \\
\text { effectiveness of the SIK. }\end{array}$ & \begin{tabular}{|l} 
8. \\
Health Information \\
System \\
Implementation
\end{tabular} \\
\hline 10 & $\begin{array}{l}\text { Mmereki, R. } \\
\text { N., \& Moruisi, } \\
\text { K. G. (2013) }\end{array}$ & $\begin{array}{l}\text { The identified failure factors include } \\
\text { organizational resistance, lack of organizational } \\
\text { readiness to change, lack of training and } \\
\text { education, problems related to commitment and } \\
\text { leadership support, problems related to } \\
\text { continuity, problems related to integration } \\
\text { mechanisms, job definition and allocation of } \\
\text { responsibilities, problems related to BPR } \\
\text { resources, ineffective use of consultants, and } \\
\text { improper integration of information systems. }\end{array}$ & 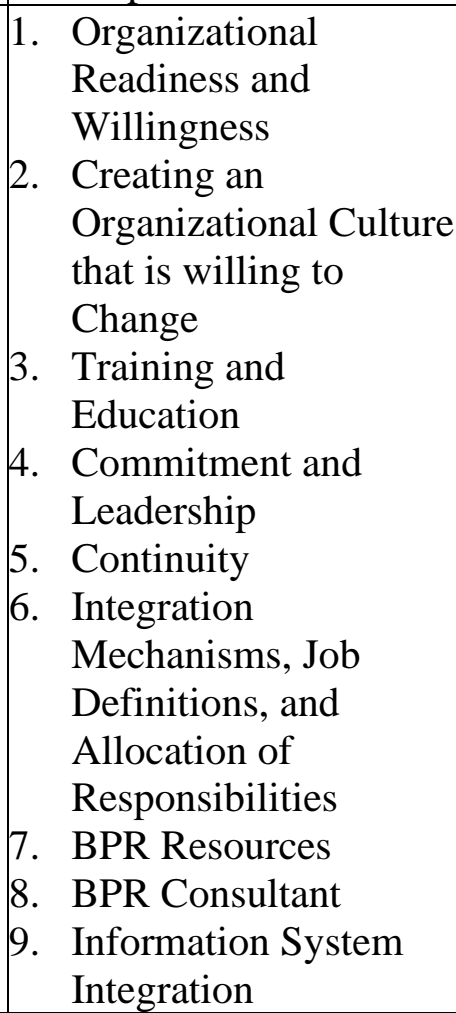 \\
\hline
\end{tabular}

Table 3. Mapping Study Results Based on Research Concept Framework

\begin{tabular}{|c|c|c|}
\hline Key Factor Groups & factor & Research (Citasi) \\
\hline \multirow[t]{3}{*}{ Management Commitment } & $\begin{array}{l}\text { Top Management } \\
\text { Commitment }\end{array}$ & \multirow[t]{3}{*}[2]{$,[3],[5],[6],[8],[9]$, and [10] } \\
\hline & Management Support & \\
\hline & $\begin{array}{l}\text { Organization Readiness and } \\
\text { Willingness }\end{array}$ & \\
\hline \multirow[t]{7}{*}{ Employee Empowerment } & Human Resources & \multirow[t]{7}{*}{ [1], [5], [7], [8], [9], and [10]. } \\
\hline & Staff Participation & \\
\hline & Health Care Education & \\
\hline & Bpr Project Team Cohesion & \\
\hline & BPR Project Team Expertise & \\
\hline & Staff Training & \\
\hline & $\begin{array}{l}\text { Integration Mechanisms, Job } \\
\text { Definitions, and Allocation of } \\
\text { Responsibilities }\end{array}$ & \\
\hline Methods and Tools & $\begin{array}{l}\text { Selection of Methods and } \\
\text { Tools }\end{array}$ & [4] \\
\hline Information Technology & $\begin{array}{l}\text { Information Technology } \\
\text { Support }\end{array}$ & [3], [4], [6], [8], [9], and [10]. \\
\hline
\end{tabular}

Copyright @ 2021, Journal of Asian Multicultural Research for Medical and Health Science Study, Under the license CC BY-SA 4.0 


\begin{tabular}{|c|c|c|}
\hline Key Factor Groups & factor & Research (Citasi) \\
\hline & $\begin{array}{l}\text { Implementation of Health } \\
\text { Information System }\end{array}$ & \\
\hline & $\begin{array}{l}\text { Information System } \\
\text { Integration }\end{array}$ & \\
\hline \multirow[t]{3}{*}{ Environment and Culture } & $\begin{array}{l}\text { Collaborative Work } \\
\text { Environment }\end{array}$ & \multirow[t]{3}{*}{ [3], [6], [7], and [10]. } \\
\hline & $\begin{array}{l}\text { Behavior and Performance } \\
\text { Feedback }\end{array}$ & \\
\hline & $\begin{array}{l}\text { Creating a Culture of } \\
\text { Organization that wants to } \\
\text { Change }\end{array}$ & \\
\hline External Organization & $\begin{array}{l}\text { Communication and } \\
\text { collaboration between BPR } \\
\text { Staff and Consultants }\end{array}$ & [9] \\
\hline \multirow[t]{8}{*}{ BPR Project } & Business Process Renovation & \multirow[t]{8}{*}[2]{$,[5],[8],[9]$, and [10]. } \\
\hline & Automation Process & \\
\hline & BPR Process Indicators & \\
\hline & BPR Implementation Process & \\
\hline & Sponsorship for BPR Project & \\
\hline & Continuity & \\
\hline & BPR Resources & \\
\hline & BPR Consultant & \\
\hline Financial & Financial Resources & [1], [3], and [6]. \\
\hline \multirow[t]{2}{*}{ strategy } & Strategy Synchronization & \multirow[t]{2}{*}{ [4] and [9] } \\
\hline & Clear Purpose & \\
\hline
\end{tabular}

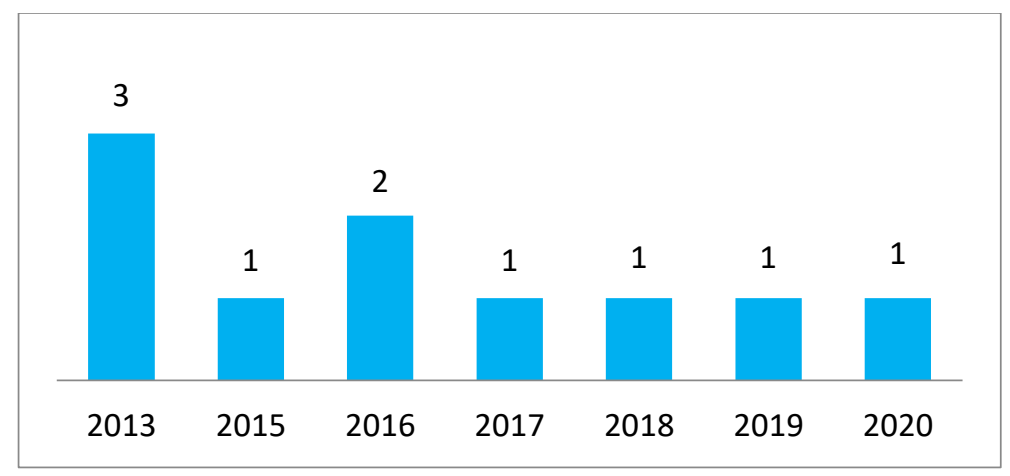

Figure 2. Articles by Year of Publication

Of the 10 articles analyzed in this study, the articles published in 2013 were the most with three articles. This means that there is still a lack of research articles related to the success factors of BPR in hospitals that have been published recently. The most articles were from Nigeria, Ethiopia, and Australia, which were two articles each (Figure 3) and the articles that conducted research on public hospitals were the most with five articles (Figure 4). 


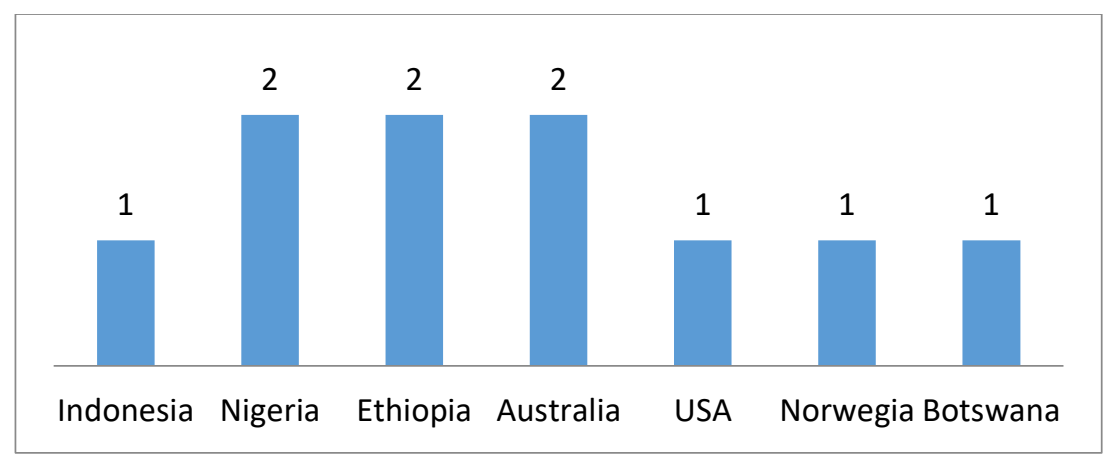

Figure 3. Articles by Country

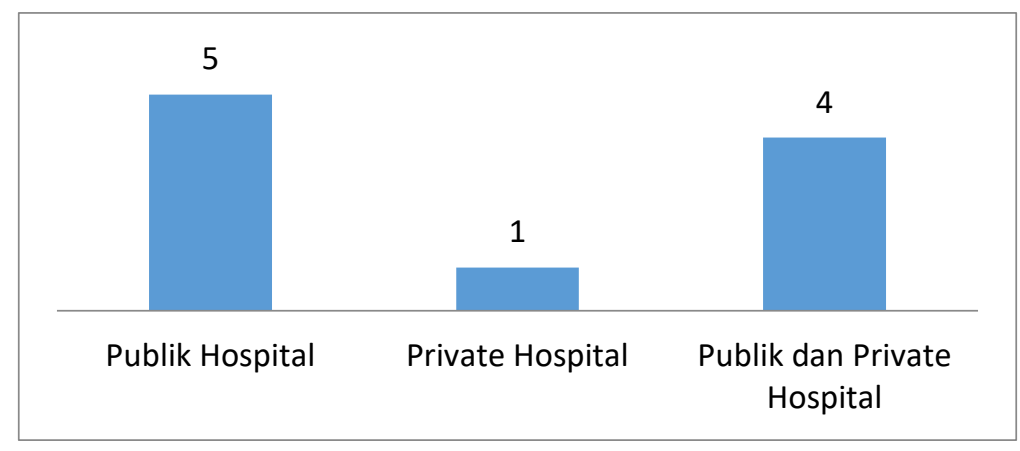

Figure 4. Articles by Hospital Type

In general, the main cause of failure of BPR implementation in public and private organizations is the lack of leadership involvement (Dennis et al., 2003). In terms of management commitment, hospitals can build efficient and accountable leadership and governance, provide stakeholders with a common understanding of BPR reform, and commit to continuous improvement in implementing BPR projects (Caccia-Bava et al., 2013; G. Leggat et al., 2016; Manyazewal et al., 2016; Manyazewal \& Matlakala, 2018). Providing understanding is very important for hospitals to do because with the same understanding regarding BPR, it will be the starting point for setting the same targets and objectives and project execution will be more focused. According to Hammer and Stanton (1995) that organizational leaders who try to implement process improvement and reengineering efforts fail not because of employee resistance to change but because of how leaders manage and handle change and support or not support change efforts (Dell 'aquila, 2017). People and their behavior can influence the successful design and implementation of a process, redesign or BPR initiative (Xiang et al., 2014).

Other success factors in terms of employee empowerment are improving the performance of the BPR team in terms of process expertise, appointing and empowering a champion as a project manager, and involving supervisors in the reengineered department to work with the champion (Caccia-Bava et al., 2013; Leggat et al., 2015; Mmereki \& Moruisi, 2013). Employee skills can be improved through adequate training and education. according to Kruger (2017) the role of a champion is very important in ensuring the success of a BPR project. Champion who will be responsible for helping stakeholders (in this case people affected by process changes) to understand the project and advise them on the expected results. Then choosing a champion or project manager will also make it easier to control the BPR project because it is the champion who will be directly responsible to the leadership regarding the project changes made. 
In terms of information technology (IT), the hospital can work closely with the IT department, maximize innovation and use of health technology, information systems must be integrated during the BPR program so that there is no duplication of activities, the effectiveness of information technology is adequately measured, ensuring that the information technology infrastructure is aligned with BPR strategy (Caccia-Bava et al., 2013; Manyazewal et al., 2016; Musa, 2017). According to Chen (2001) BPR is known by many names, including core process redesign, new industrial engineering and working smarter. They all imply the same concept that focuses on integrating business process redesign and using IT to support reengineering work. Therefore, it is very important for hospitals to ensure the integration of information technology during the BPR project.

A hospital that will make changes and run a BPR project must pay attention to how its environment and culture accept it (Leggat et al., 2015; Manyazewal et al., 2016; Manyazewal \& Matlakala, 2018; Mmereki \& Moruisi, 2013). One of the things that hospitals can do is foster a healthy and respectful work environment and build a culture to want to change to be more advanced. The business-as-usual process culture needs to be overcome if the success of the BPR project is to be guaranteed, as the old culture has proven to be inadequate. Without cultural change, the breakthrough changes required for a successful BPR project would never occur. Cultural change is the single most significant dynamic affecting the achievement of BPR project objectives (Kruger, 2017). If the culture remains unchanged, employees will return to their previous business processes.

In addition to the internal environment, one of the factors that the hospital focuses on is the hospital's external environment. Hospitals should focus on market demands and involve some outside people even customers if possible who know the full process (Khodambashi, 2013; Musa, 2017). According to Dennis et al. (2003) it is important to ensure horizontal participation in BPR projects (ie, actively involve the "customers" and "suppliers" of the process, both external and internal), as they will be affected by change. In addition, hospitals must also understand the service areas that still often lead to patient dissatisfaction such as lack of medicines and supplies, poor information provision, long waiting times, poor hygiene, lack of privacy and inadequate visiting hours so it is necessary to plan for delivery. better service through process redesign (Assefa et al., 2011).

BPR projects are known as high-cost and high-risk activities, including in the hospital industry. Study by Manyazewal et al. (2016) identified limited financial resources and a poor health financing system as the main factors influencing the implementation of health reform. Adequate financial conditions will certainly make it easier for hospitals to make business process changes. So from a financial perspective, hospitals should secure resources for BPRs and make efficient use of hospital financing (Manyazewal et al., 2016; Mmereki \& Moruisi, 2013) especially for public hospitals which in general always experience limitations in terms of funding sources and have inefficient service processes.

The implementation of BPR projects in hospitals is indeed quite complicated and not easy to carry out. Hospitals must select professionals in the field of BPR in carrying out their practice, appoint a BPR team, train them and then make the team a benchmark with other public sector organizations, not reengineer several processes at once, choose BPR projects that have strategic importance, mapping program results Regular BPR (Caccia-Bava et al., 2013; Leggat et al., 2015; Manyazewal \& Matlakala, 2018; Mmereki \& Moruisi, 2013; Musa, 2017). The BPR process should also be carried out in stages and not all at once because each process requires maximum attention and implementation. Likewise, with methods and tools, hospitals should choose the best methods and tools that can distinguish productive activities from non-valueadded activities. and simulate tradeoffs between the dimensions of time, cost, quality and

Copyright @ 2021, Journal of Asian Multicultural Research for Medical and Health Science Study, Under the license CC BY-SA 4.0 
flexibility, because an increase in one factor can adversely affect the other (Khodambashi, 2013; Musa, 2017). For example, this tradeoff simulation can evaluate the cost or time for a redesigned process (Jensen-Vullers \& Reijers, 2005).

\section{Conclusion}

Based on the results of the research above, the key success factors in implementing Business Process Re-Engineering (BPR) in hospitals are management commitment, employee empowerment, methods and tools, information technology, environment and culture, external organization, BPR projects, finance and strategy. These factors are only general of the many other factors that can affect the implementation of BPR in hospitals because hospitals are heterogeneous and of course influenced by various different factors.

\section{References}

Al-fawaeer, M., Ridha, M. B., \& Yousif, A. S. H. (2019). An investigation into The Relationship between Business Processes Re-engineering ( BPR ) and Employees , Performance : An Empirical Study at The Jordanian Public Shareholding companies. Review of Applied Socio-Economic Research, 17(1), 5-17.

Al-Mashari, M., Irani, Z., \& Zairi, M. (2001). Business Process Reengineering: A Survey of International Experience. Business Process Management Journal, 7(5), 437-455. https://doi.org/10.1108/14637150110406812

Al Badi, K. (2018). Discrete Event Simulation and Pharmacy Process Re-engineering. International Journal of Health Care Quality Assurance, 32(2), 398-411. https://doi.org/doi.org/10.1108/IJHCQA-05-2018-0105

Arinahaq, A., \& Achadi, A. (2019). Factors Associated with Business Process in Hospital: A Systematic Review. In 6th International Conference on Public Health 2019, 270-278. https://doi.org/10.26911/the6thicph.04.30

Assefa, F., Mosse, A., \& H/Michael, Y. (2011). Assessment of Clients' Satisfaction with Health Service Deliveries at Jimma University Specialized Hospital. Ethiopian Journal of Health Sciences, 21(2), 101-109. https://doi.org/10.4314/ejhs.v21i2.69050

Blouin-Delisle, C. H., Drolet, R., Gagnon, S., Turcotte, S., Boutet, S., Coulombe, M., \& Daneau, E. (2018). Improving Flow in The OR: How Lean Process Studies Can Lead to Shorter Stays in The Recovery Ward. International Journal of Health Care Quality Assurance, 31(2), 150-161. https://doi.org/https://doi.org/10.1108/IJHCQA-01-20170014

Boudreau, M. C., \& Robey, D. (1996). Coping with Contradictions in Business Process Reengineering. Information Technology \& People, 9(4), 40-57. https://doi.org/10.1108/09593849610153421

Brennan, A., Sampson, F., Deverill, M., \& Court, R. (2005). Can We Use Routine Data to Evaluate Organizational Change ? Lessons From The Evaluation of Business Process Re-engineering in a UK Teaching Hospital. Health Services Management Research, 18(4), 265-276. https://doi.org/doi.org/10.1258/095148405774518651

Caccia-Bava, M. C., Guimaraes, V. C. K., \& Guimaraes, T. (2013). Important Factors for Success in Hospital BPR Project Phases. International Journal of Health Care Quality Assurance, 26(8), 729-745. https://doi.org/10.1108/IJHCQA-01-2012-0007

Chen, Y.-C. (2001). Empirical Modellig for Participative Business Process Reengineering. University of Warwick, United Kingdom. 
Dell 'aquila, M. E. (2017). Factors Contributing to Business Process Reengineering Implementation https://search.proquest.com/dissertations/docview/1867020905/60CCB10BA7EE47 AEPQ/35? accountid=28547

Dennis, A. R., Carte, T. A., \& Kelly, G. G. (2003). Breaking The Rules: Success and Failure in Groupware-supported Business Process Reengineering. Decision Support Systems, 36(1), 31-47. https://doi.org/10.1016/S0167-9236(02)00132-X

Elkhuizen, S. G., Limburg, M., \& Klazinga, N. S. (2006). Evidence-Based Re-engineering: Re-engineering The Evidence. International Journal of Health Care Quality Assurance, 477-499. https://doi.org/10.1108/09526860610686980

Feibert, D. C., Andersen, B., \& Jacobsen, P. (2019). Total Quality Management \& Business Excellence Benchmarking Healthcare Logistics Processes - A Comparative Case Study of Danish and US hospitals. Total Quality Management \& Business Excellence, 30(1-2), 108-134. https://doi.org/10.1080/14783363.2017.1299570

G. Leggat, S., Gough, R., Bartram, T., Stanton, P., Bamber, G. J., Ballardie, R., \& Sohal, A. (2016). Process Redesign for Time-Based Emergency Admission Targets: Staff Perceptions of The Impact on Quality of Care. Journal of Health, Organisation and Management, 30(6), 939-949. https://doi.org/10.1108/JHOM-08-2015-0114

Grocott, M. P. W., Plumb, J. O. M., Edwards, M., Fecher-jones, I., \& Levett, D. Z. H. (2017). Re-designing The Pathway to Surgery : Better Care and Added Value. Perioperative Medicine, 6(1), 1-7. https://doi.org/10.1186/s13741-017-0065-4

Helfert, M. (2009). Challenges of Business Processes Management in Healthcare Experience in the Irish healthcare sector. Business Process Management Journal, 15(6), 937-952. https://doi.org/10.1108/14637150911003793

Jamali, G., Abbaszadeh, M. A., Ebrahimi, M., \& Maleki, T. (2011). Business Process Reengineering Implementation: Developing a Causal Model of Critical Success Factors. International Journal of E-Education, e-Business, e-Management and $e$ Learning, 1(5), 354-359.

Jensen-Vullers, M. H., \& Reijers, H. A. (2005). Business Process Redesign at A Mental Healthcare Institute: A Coloured Petri Net Approach. Proceedings of the Sixth Workshop and Tutorial on Practical Use of Coloured Petri Nets and the CPN Tools (PB-576), 21-38. https://doi.org/10.7146/dpb.v38i590.7187

Khodambashi, S. (2013). Business Process Re-engineering Application in Healthcare in a Relation to Business Process Re-Engineering Application in Healthcare in a relation to Health Information Systems. Procedia Technology, 9, 949-957. https://doi.org/10.1016/j.protcy.2013.12.106

Kohlbacher, M. (2010). The Effects of Process Orientation: a Literature Review. Business Process Management Journal, 16(1), 135-152. https://doi.org/10.1108/14637151011017985

Kruger, D. (2017). Application of Business Process Reengineering as a Process Improvement Tool: A Case Study. Proceedings of PICMET '17: Technology Management for Interconnected World.

Leggat, S. G., Bartram, T., Stanton, P., Bamber, G. J., \& Sohal, A. S. (2015). Have process redesign methods, such as Lean, been successful in changing care delivery in hospitals? A systematic review. Public Money and Management, 35(2), 161-168. 
https://doi.org/10.1080/09540962.2015.1007714

Manyazewal, T., \& Matlakala, M. C. (2018). Implementing health care reform: Implications for performance of public hospitals in central Ethiopia. Journal of Global Health, 8(1). https://doi.org/10.7189/jogh.08.010403

Manyazewal, T., Oosthuizen, M. J., \& Matlakala, M. C. (2016). Proposing evidence-based strategies to strengthen implementation of healthcare reform in resource-limited settings: a summative analysis. BMJ Open, 6(9), e012582. https://doi.org/10.1136/bmjopen-2016-012582

Mmereki, R. N., \& Moruisi, K. G. (2013). Challenges in Implementation of Business Process Re-Engineering in Botswana Public Hospitals. International Journal on Customer Relations, 1(1), 31-37.

Musa, M. A. (2017). Critical Success Factor in Business Process Reengineering In Healthcare: An Exploratory Investigations. Journal of Multidisciplinary Engineering Science and Technology (JMEST), 4(7), 7597-7605.

Musa, M. A., \& Othman, M. S. (2016). Business Process Reengineering in Healthcare: Literature Review on the Methodologies and Approaches. Review of European Studies, 8(1), 20-34. https://doi.org/10.5539/res.v8n1p20

O’Neill, P., \& Sohal, A. S. (1999). Business Process Reengineering a Review of Recent Literature. Technovation, 19(9), 571-581. https://doi.org/doi.org/10.1016/S01664972(99)00059-0

Patwardhan, A., \& Patwardhan, D. (2008). Business Process Re-engineering - Saviour or Just Another Fad? One UK Health Care Perspective. International Journal of Health Care Quality Assurance, 21(3), 289-296. https://doi.org/10.1108/09526860810868229

Pujawan, I. N. (2007). Aplikasi Lean Thinking Pada Instalasi Rawat Inap Rumah Sakit Semen Gresik.

Putra, C. A., \& Puspitorini, S. P. (2017). Pemodelan Business Process Reengineering IKM Batik Menggunakan Value Chain Untuk Meningkatkan Locational Advantage. Majapahit Techno, 6(2), 1-8.

Rao, L., Mansingh, G., \& Osei-Bryson, K. M. (2012). Building Ontology Based Knowledge Maps to Assist Business Process Re-engineering. Decision Support Systems, 52(3), 577-589. https://doi.org/10.1016/j.dss.2011.10.014

Rateb, S. A. H., El Nouman, A. A. R., Rateb, M. A. H., Asar, M. N., El Amin, A. M., Gad, S. abdel A., \& Mohamed, M. S. E. (2011). Re-engineering Pre-employment Check-up Systems: A Model for Improving Health Services. International Journal of Health Care Quality Assurance, 24(6), 484-497. https://doi.org/10.1108/09526861111150734

Ruffin, T. R. (2016). Quantitative Analysis of Business Process Reengineering Deployment in Health Information Technology. Advanced Health Care Technologies, 2, 31-42. https://doi.org/10.2147/ahct.s101946

Sungau, J. (2013). Business Process Re-engineering: The Technique to Improve Delivering Speed of Service Industry in Tanzania. Independent Journal of Management \& Production, 4(1), 208-227. https://doi.org/10.14807/ijmp.v4i1.68

Xiang, J., Archer, N., \& Detlor, B. (2014). Business process redesign project success: The role of socio-technical theory. Business Process Management Journal, 20(5), 773-792.

Copyright $@$ 2021, Journal of Asian Multicultural Research for Medical and Health Science Study,

Under the license CC BY-SA 4.0 